\title{
A contribution to the knowledge of jumping spiders from Thailand (Aranei: Salticidae)
}

\section{K познанию пауков-скакунчиков Таиманда (Aranei: Salticidae)}

\author{
R.R. Seyfulina ${ }^{1}$, G.N. Azarkina ${ }^{2}$, V.M. Kartsev ${ }^{3}$ \\ P.P. Сейфулина ${ }^{1}$, Г.Н. Азаркина ${ }^{2^{*}}$, В.М. Карцев ${ }^{3}$
}

\begin{abstract}
${ }^{1}$ Prioksko-Terrasnyi State Biosphere Reserve, Danki, Moscow Area 142200, Russia. E-mail: r-seyfulina@yandex.ru Приокско-Террасный государственный природный биосферный заповедник, Московская область, м. Данки 142200, Россия. ${ }^{2}$ Laboratory of Systematics of Invertebrate Animals, Institute of Systematics and Ecology of Animals, Siberian Branch of the Russian Academy of Sciences, Frunze street 11, Novosibirsk 630091, Russia.

Лаборатория систематики беспозвоночных животных, Институт систематики и экологии животных СО РАН, ул. Фрунзе, 11, Новосибирск 630091, Россия.

${ }^{3}$ Department of Entomology, Faculty of Biology, Lomonosov Moscow State University, Leninskie Gory, Moscow 119234, Russia.

Кафедра энтомологии Биологического факультета Московского государственного университета имени М.В. Ломоносова, Ленинские Горы, Москва 119234, Россия.

* Corresponding author
\end{abstract}

KEY WORDS: Araneae, Arachnida, fauna, Oriental Region, Tarutao National Park.

КЛЮЧЕВЫЕ СЛОВА: Araneae, Arachnida, фауна, Ориентальная область, Национальный парк Тарутаo.

ABSTRACT. Jumping spiders of 10 species collected from Satun, Sukhotai and Kanchanaburi Provinces of Thailand are studied. Six species are reported from the country for the first time: Evarcha bulbosa Żabka, 1985, Phintella vittata (C.L. Koch, 1846), Phintelloides versicolor (C.L. Koch, 1846), and Portia labiata (Thorell, 1887). Two of them are new to the fauna of Indo-China (Holoplatys digitatus Zhou, Irfan et Peng, 2017 and Menemerus nigli Wesołowska et Freudenschuss, 2012). Three species - M. brachygnathus (Thorell, 1887), Plexippus paykulli (Audouin, 1826 ) and $P$. setipes Karsch, 1879 - have the southernmost records of their distribution in Thailand. One species - Stenaelurillus abramovi Logunov, 2008 has a southernmost limit of its range. Photos of living specimens for eight species, as well as drawings of the copulatory organs for $H$. digitatus and $M$. nigli are provided.

How to cite this article: Seyfulina R.R., Azarkina G.N., Kartsev V.M. 2020. A contribution to the knowledge of jumping spiders from Thailand (Aranei: Salticidae) // Arthropoda Selecta. Vol.29. No.1. P.87-96. doi: 10.15298/arthsel. 29.1.07

РЕЗЮМЕ. Изучены пауки-скакунчики 10 видов, собранных в Таиланде в провинциях Сатун, Сукхотай, Канчанабури. Шесть видов отмечены впервые в стране: Evarcha bulbosa Żabka, 1985, P. vittata (C.L. Koch, 1846), Phintelloides versicolor (C.L. Koch, 1846) и Portia labiata (Thorell, 1887). Два из них новые для фауны Индокитая: Holoplatys digitatus Zhou, Irfan et Peng, 2017 и Menemerus nigli Wesołowska et Freudenschuss, 2012. Для трёх видов - $M$. brachygnathus (Thorell, 1887), Plexippus paykulli (Audouin, 1826) и P. setipes Karsch, 1879 - отмечены самые южные точки распространения в Таиланде, для Stenaelurillus abramovi Logunov, 2008 самая южная точка ареала. Приводятся фотографии живых особей для восьми видов, для H. digitatus и M. nigli приводятся рисунки копулятивных органов.

\section{Introduction}

Salticidae represent the most speciose and genus reach spider family, with more than 6000 species and around 650 genera being described from all over the world [WSC, 2020]. The world knowledge of jumping spiders is hardly exhaustive as far as their faunal inventory concerns. Many countries of the Oriental Region still have short lists of the recorded salticids, far from a completion. Thus, 48 species of the jumping spiders have been reported from Thailand, which is a surprisingly low number compared to neighbouring Vietnam (126 sp.) or Malaysia (278 sp.) [Metzner, 2020].

The first data about Thai representatives of the family were published by Giebel [1863], with all the species described by him being considered nomina dubia by Roewer in 1955 [Azarkina, 2019]. Simon [1886] reported on two species from Thailand: Telamonia hasselti (Thorell, 1878) (described as Viciria scoparia) from Chantaboun [=Chanthaburi] and Hyllus diardi (Walckenaer, 1837) from Tung Yai (Turgiai in Simon [1886]) located on the seashore near Chantaboun. Almost a century later, few new species and findings were made by Wanless [1980, 1984] and 

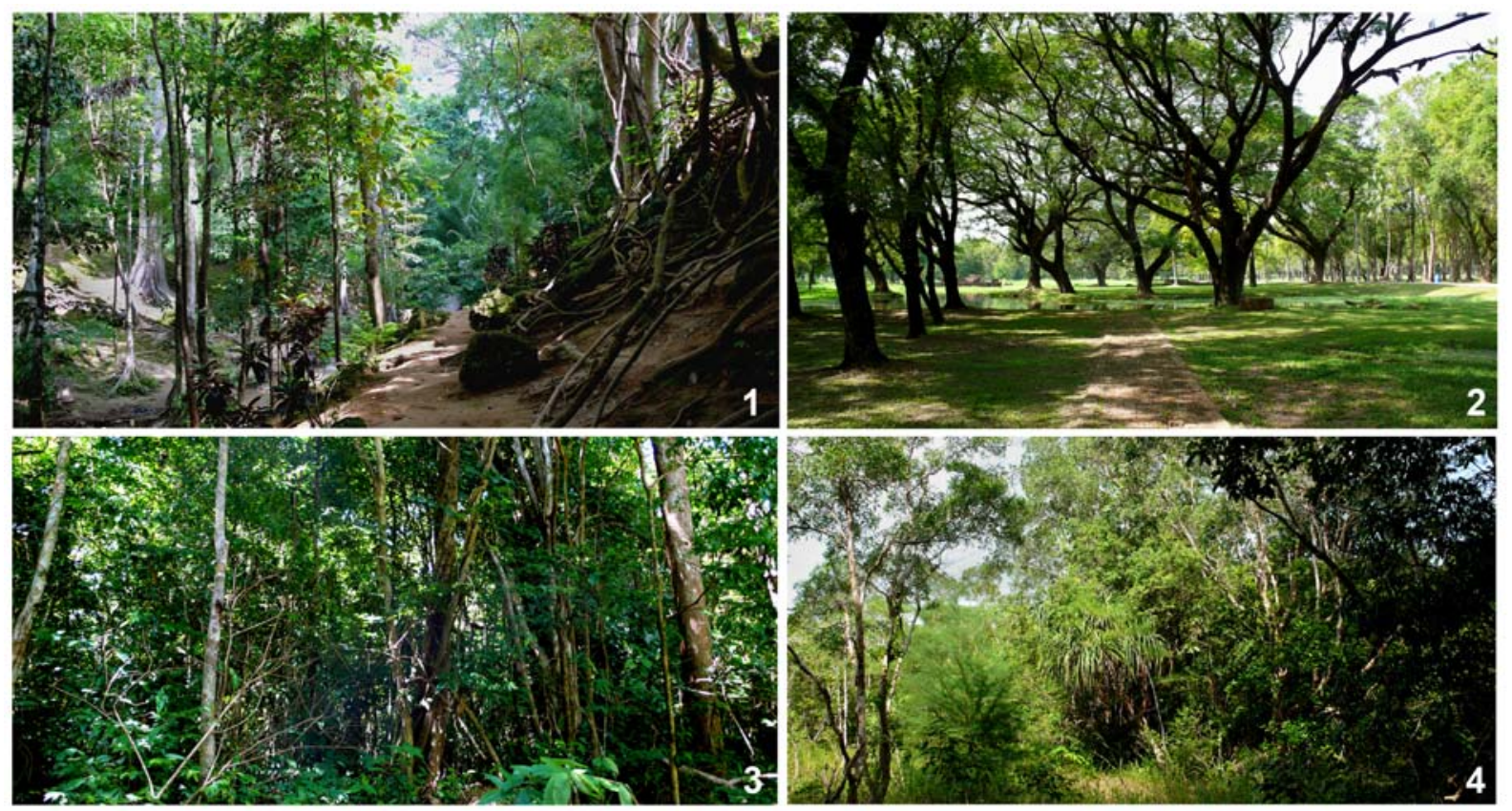

Figs 1-4. Sampling sites. 1 - Sukhotai Historical Park; 2 - Sai Yok Noi Waterfall surroundings; 3-4 - Tarutao National Park.

Рис. 1-4. Места сборов. 1 - Исторический парк Сукхотай; 2 - окрестности водопада Сай Йок Ной; 3-4 - Национальный парк Тарутао.

Prószyński [1992a]. Twelve new salticids were recently described from Thailand [Benjamin, 2004, 2010; Logunov, Hereward, 2006; Logunov, Azarkina, 2008; Prószyński, Deeleman-Reinhold, 2012; Yamasaki, Ahmad, 2013; Logunov, Marusik, 2014; Azarkina, 2019], as well as new faunistic and/or behavioral information was provided [Chotwong, Tanikawa, 2013; Grob, 2015; Logunov, 2019].

A critical survey of Salticidae from Thailand was published by Żabka \& Gardzińska [2017]. They provided the latest checklist of Salticidae from Thailand subdivided into two parts: 'Confirmed species' (part 1) with 33 species, and 'Species to be confirmed' (part 2) with 13 species. Both parts provide data on a general distribution and regional records from Thailand for each listed species.

The aims of the present paper are: (1) to provide new records for the species collected during the 2014 field trip to Thailand; (2) to illustrate Holoplatys digitatus and Menemerus nigli, the species that display an unusual distribution and are recorded far from their known ranges; (3) to provide photographs of live specimens for eight species; and (4) to compose an updated and revised checklist of the Thai jumping spiders.

\section{Material and Methods}

A total of 13 specimens of Salticidae belonging to 10 species of eight genera has been studied. Specimens have been deposited in the Institute of Systematics and Ecology of Animals SB RAS (ISEA, curator G.N. Azarkina). Each species listed below is provided with the information about its general distribution and habitat preferences. Each species recorded from Thailand for the first time is marked with an asterisk $(*)$. For known species, only references to their original descriptions and records from Thailand are listed; full reference lists for each species can be found in WSC [2020].

Specimens were collected by the first author during a short fieldtrip to Thailand in November 2014. The specimens were photographed in the sampling plots and/or were taken alive to the laboratory and then photographed with the aid of digital camera Nikon D810. Then specimens were preserved with $75 \%$ alcohol. Two preserved species were photographed using digital camera Canon EOS 550D attached to Zeiss Stemi 2000-C at the ISEA. Focal planes of a single image stack were combined by using the Helicon Focus 6.3 software. All drawings were edited and assembled in Adobe Photoshop CS5. Distributional map was produced by using the online mapping software SimpleMappr [Shorthouse, 2010].

List of the surveyed localities in Thailand (Map) is as follows: 1 - Kanchanaburi Province, Sai Yok District, near Sai Yok Noi Waterfall $\left(14^{\circ} 14^{\prime} 20.5^{\prime \prime} \mathrm{N}, 99^{\circ} 03^{\prime} 29.0^{\prime \prime} \mathrm{E}\right), 8.11$. 2014; 2 - Sukhothai Province, Mueang Sukhothai District, Mueang Kao, Sukhothai Historical Park $\left(17^{\circ} 01^{\prime} \mathrm{N}, 99^{\circ} 42^{\prime} \mathrm{E}\right)$, 20.11.2014; $3 \mathrm{a}$ - Satun Province, Mueang Satun District, Kho Tarutao Island, Tarutao National Park $\left(6^{\circ} 41^{\prime} 39.5^{\prime \prime} \mathrm{N}\right.$, 99 $\left.38^{\prime} 41.5^{\prime \prime} \mathrm{E}\right), 25.11 .2014 ; 3 \mathrm{~b}$ - Satun Province, Mueang Satun District, Kho Tarutao Island, Tarutao National Park $\left(6^{\circ} 41^{\prime} 38.6^{\prime \prime} \mathrm{N}, 99^{\circ} 38^{\prime} 41.7^{\prime \prime} \mathrm{E}\right), 25.11 .2014 ; 3 \mathrm{c}$ - Satun Province, Mueang Satun District, Kho Tarutao Island, Tarutao National Park $\left(6^{\circ} 40^{\prime} 55^{\prime \prime} \mathrm{N}, 99^{\circ} 38^{\prime} 43^{\prime \prime} \mathrm{E}\right), 25-26.11 .2014$. The site-3 is mapped as one dot (Map: 3 ) because all three sites are very close to each other: $3 \mathrm{a}$ and $3 \mathrm{~b}$ are separated by 0.15 $\mathrm{km}, 3 \mathrm{~b}$ and $3 \mathrm{c}$ by about $1.35 \mathrm{~km}$. Yet, in the following species survey, a precise reference to $3 \mathrm{a}, 3 \mathrm{~b}$ or $3 \mathrm{c}$, as well as to site- 1 and 2 , is provided in square brackets for each species. 


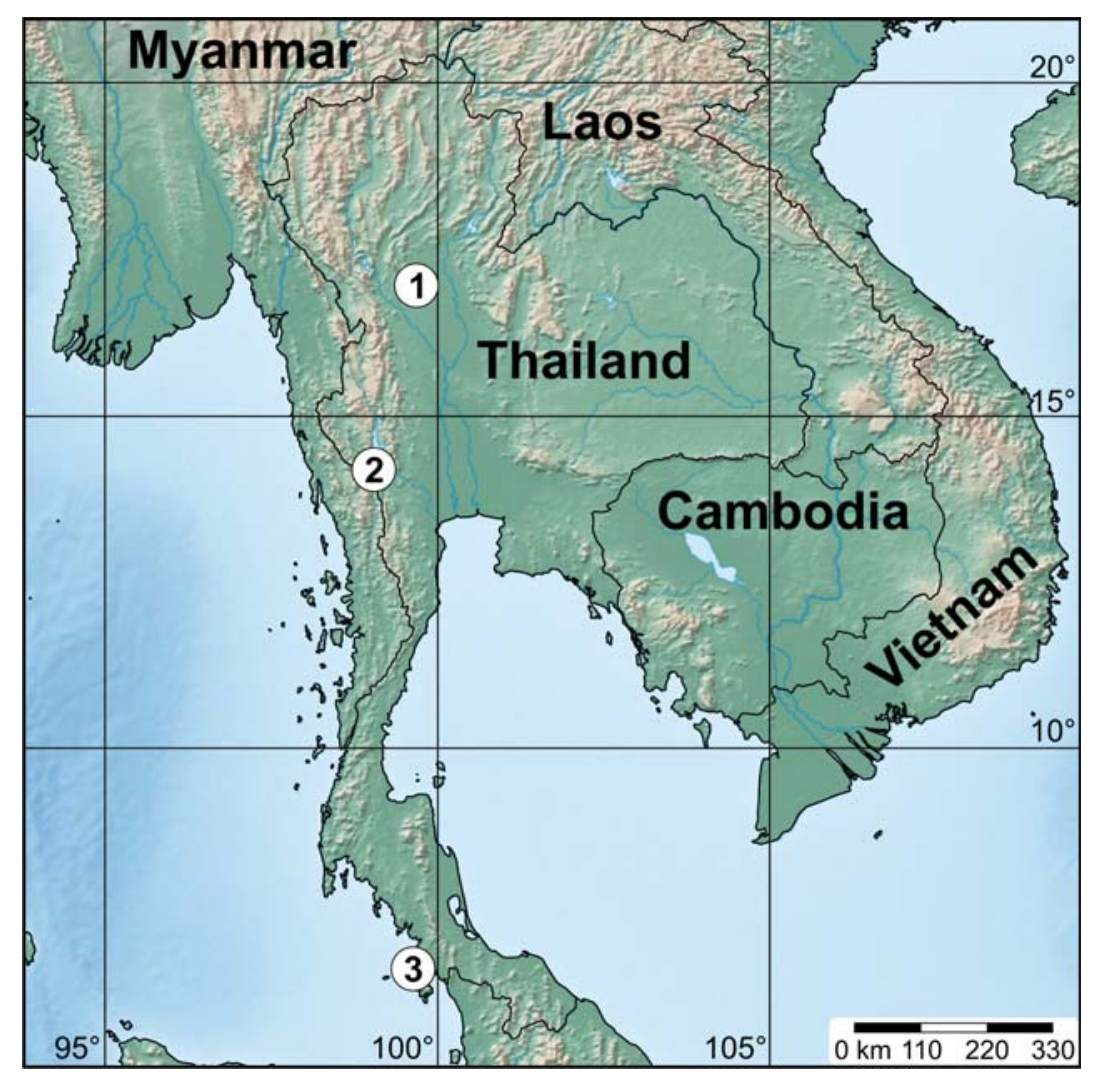

Map. Collecting localities: 1 - Sai Yok Noi Waterfall surroundings; 2 - Sukhothai Historical Park; 3 - Tarutao National Park.

Карта. Точки сборов: 1 - окрестности водопада Сай Йок Ной; 2 - Исторический парк Сукхотай; 3 - Национальный парк Тарутао.

The site in Kanchanaburi Province (Fig. 1, Map: 1) is located in the immediate proximity to the Sai Yok Noi Waterfall. It is covered primarily by Ficus spp., and the grass undergrowth was visually examined in search for spiders.

The site in Sukhotai Province (Fig. 2, Map: 2) is situated in the Sukhothai Historical Park (Mueang Kao), which covers some 70 square kilometers. Spiders were collected mostly from trunks of the trees forming park alleys (Ficus spp., Cassia bakeriana Craib, Cocos nucifera L., etc.).

The site in Satun Province (Figs 3-4, Map: 3) is located in the Tarutao National Park on Kho Tarutao Island in the Straits of Malacca in the Andaman Sea, ca. $40 \mathrm{~km}$ west of the Thai shore and only $4.8 \mathrm{~km}$ from Ko Langkawi, which is part of Malaysia. About $90 \%$ of the island occupying 230 square kilometers is covered with the virgin evergreen rainforest. Main tree species are Lumpho or Malacca Teak (Intsia palembanica Miq.), Khiam (Cotylelobium melanoylon (Hook. f.) Pierre ex F. Heim), Yang Pai (Dipterocarpus costatus G. Don), Yang Sian (Dipterocarpus gracilis Blume), Daeng Kha (Eugenia spp.) and Takhian Hin (Hopea ferrea Laness.).

\section{Species survey}

Evarcha bulbosa Żabka, 1985*

Evarcha bulbosa Żabka, 1985: 222, f. 173-175.

MATERIAL. $1 \sigma^{7}$ (ISEA 001.8304) - [3c], sweeping over bushes and low vegetation.
HABITAT. Seems to be a tamnobiont: the holotype was collected from bush [Żabka, 1985], while our specimen was collected either from grass or bush.

DISTRIBUTION. An east Oriental species known from China (Hunan), Vietnam and Indonesia (Java) [Żabka, 1985; Peng, 1989; Yin et al., 2012]. Originally was described from Vietnam (the holotype) and Java (the paratype) (see Żabka [1985]); still remains known from the males only. The first record from Thailand.

Holoplatys digitatus Zhou, Irfan et Peng, 2017* Figs 5-12.

Holoplatys digitatus Zhou et al., 2017: 2, f. 1-10.

MATERIAL. $1 \sigma^{7}$ (ISEA 001.8305) - [3c], under bark.

HABITAT. The species is with a flattened body, adapted to life under tree bark (Figs 5-6, 11-12).

DISTRIBUTION. Known from China (Jiangxi, Guangdong) [Zhou et al., 2017; WSC, 2020]. The first record from Thailand and Indo-China, and outside of the type locality.

Menemerus brachygnathus (Thorell, 1887) Fig. 13.

Menemerus brachygnathus: Żabka, 1985: 241, f. 293-305; Żabka, Gardzińska, 2017: 230.

MATERIAL. $1 O^{7}$ (ISEA 001.8306) - [2], on tree trunk; $10^{7}$ (ISEA 001.8307) - [3b], on tree trunk.

HABITAT. Prefers vegetation and open surfaces such as tree trunks. 

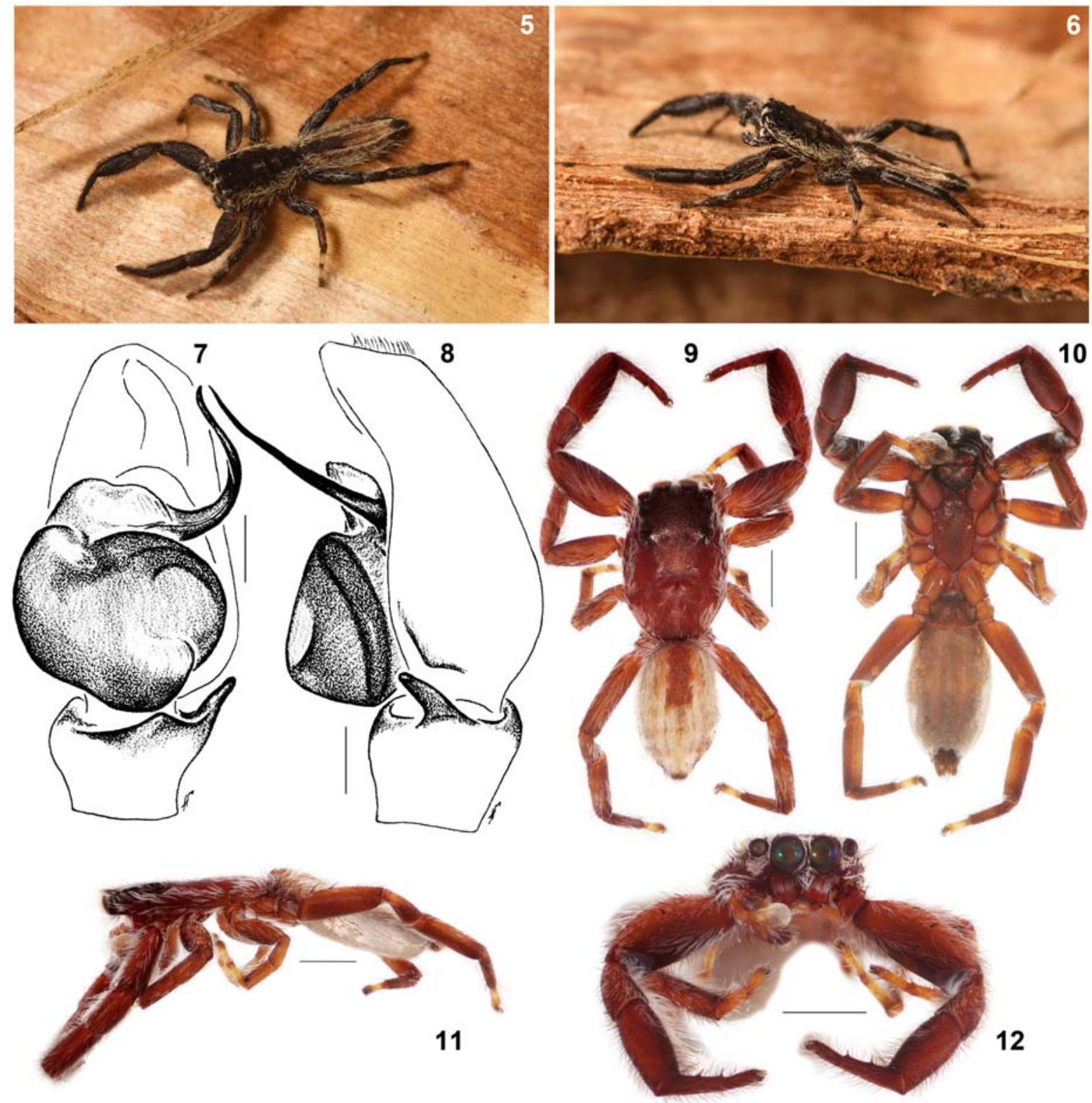

12

Figs 5-12. Holoplatys digitatus Zhou, Irfan et Peng, 2017: 5-6 - general appearance of living specimens, O'; 7 - left palp, ventral view; 8 - ditto, retrolateral view; 9-12- general appearance in alcohol, $\sigma^{7}, 9-$ dorsal view; 10 - ventral view; 11 - lateral view; $12-$ frontal view. Scale bars: $7-8-0.1 \mathrm{~mm} ; 9-12-1 \mathrm{~mm}$.

Рис. 5-12. Holoplatys digitatus Zhou, Irfan et Peng, 2017: 5-6 - внешний вид живого экземпляра, О; 7 - левая пальпа, вентрально; 8 - то же, ретролатерально; 9-12 - внешний вид в спирте, о, 9 - дорсально, 10 - вентрально; 11 - латерально; 12 - фронтально. Масштаб: 7-8 - 0,1 мм; 9-12-1 мм.

DISTRIBUTION. India throughout China (Beijing) to Japan, southward to Malaysia; reported also from Argentina [Metzner, 2020; WSC, 2020]. The southernmost locality in Thailand; previously was known from Bangkok only [Żabka, Gardzińska, 2017].

\section{Menemerus nigli Wesołowska et Freudenschuss, 2012*}

Figs 14-19. $1-6$.
MATERIAL. $1 \sigma^{7}$ (ISEA 001.8308) - [2], among ruins.

HABITAT. Found under/on stones [Wesołowska, Freudenschuss, 2012; present data], as well as on an indoor wall [Chatterjee et al., 2017]. Life coloration of the male (Fig. 14 ) is given herein for the first time.

DISTRIBUTION. Pakistan, India [WSC, 2020] and Thailand [present data]. The easternmost record of the species; the first record from Indo-China and Indo-Malayan subregion. To date, the species has been unknown outside the Hindustan area: viz., India, Pakistan and Sri Lanka [WSC, 2020; Metzner, 2020]. The new locality lies about $2200 \mathrm{~km}$ south-eastward of the nearest known south-Asian locality 

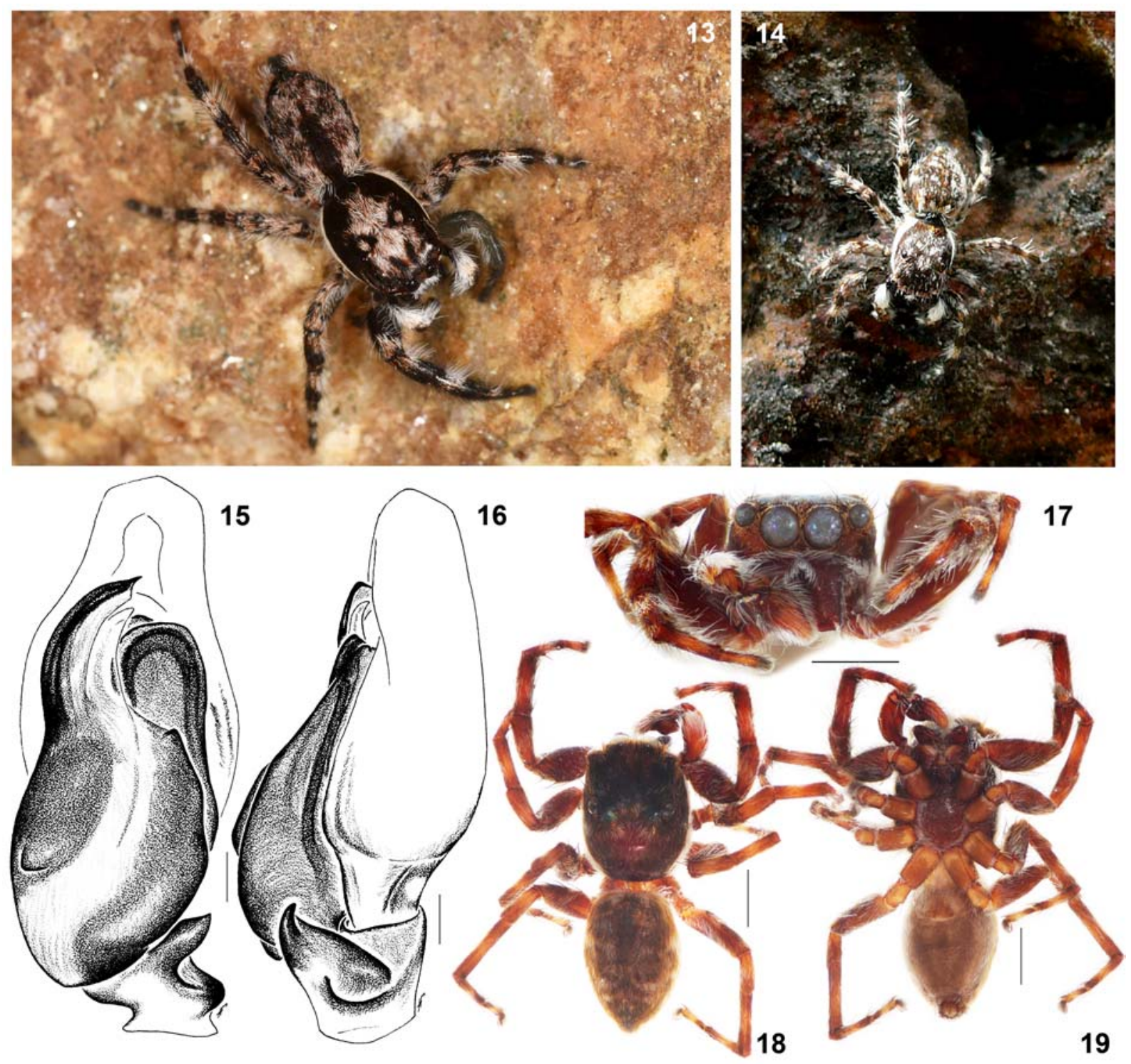

Figs 13-19. Menemerus brachygnathus (Thorell, 1887) (13) and Menemerus nigli Wesołowska et Freudenschuss, 2012 (14-19): 1314 - general appearances of living specimens, $\sigma^{7} \sigma^{7} ; 15-$ left palp, vetral view; 16 - ditto, retrolateral view; 17-19 - general appearance in alcohol, 17 - frontal view; 18 - dorsal view; 19 - ventral view. Scale bars: $15-16-0.1 \mathrm{~mm}$; $17-19-1 \mathrm{~mm}$.

Рис. 13-19. Menemerus brachygnathus (Thorell, 1887) (13) и Menemerus nigli Wesołowska et Freudenschuss, 2012 (14-19): 13-14 — внешний вид живых экземпляров, о7 $\sigma^{7} ; 15$ - левая пальпа, вентрально; 16 - то же, ретролатерально; 17-19 - внешний вид в спирте, 17 - фронтально; 18 - дорсально; 19 - вентрально. Масштаб: 15-16 — 0,1 мм; 17-19 - 1 мм.

(Behala, West Bengal) [Chatterjee et al., 2017], and 4200$4500 \mathrm{~km}$ from the type locality in Pakistan (Balochistan, Turbat) [Wesołowska, Freudenschuss, 2012], belonging to the bordering line of the Palaearctic Region. The species seems to have a wide range, which extends further eastward.

\section{Phintella vittata (C. L. Koch, 1846)*}

Plexippus vittatus C. L. Koch, 1846: 125, f. 1185. MATERIAL. $2 \mathrm{O}^{7} \mathrm{O}^{7}$ (ISEA 001.8310) - [3c].

HABITAT. Occurs on bushes and low vegetation [Roy et al., 2016]. We observed specimens in grass and once on a silk threat suspending down from upper vegetation.

DISTRIBUTION. India to the Philippines and Indonesia
[Metzner, 2020; WSC, 2020]. The first record from Thailand.

Phintelloides versicolor (C. L. Koch, 1846)*

Figs 20-21.

Plexippus versicolor C.L. Koch, 1846: 103, f. 1165.

MATERIAL. 1 (ISEA 001.8309) - [2], on tree trunk.

HABITAT. A dendrobiont, occurring mostly on tree branches and leaves [Kim, Lee, 2014]. Found on a tree trunk (Fig. 20).

DISTRIBUTION. Distributed throughout the Oriental Region and Eastern Palaearctics, from India to Japan and Indonesia. Introduced to USA (Hawaii) [Metzner, 2020; WSC, 2020]. The first record from Thailand. 

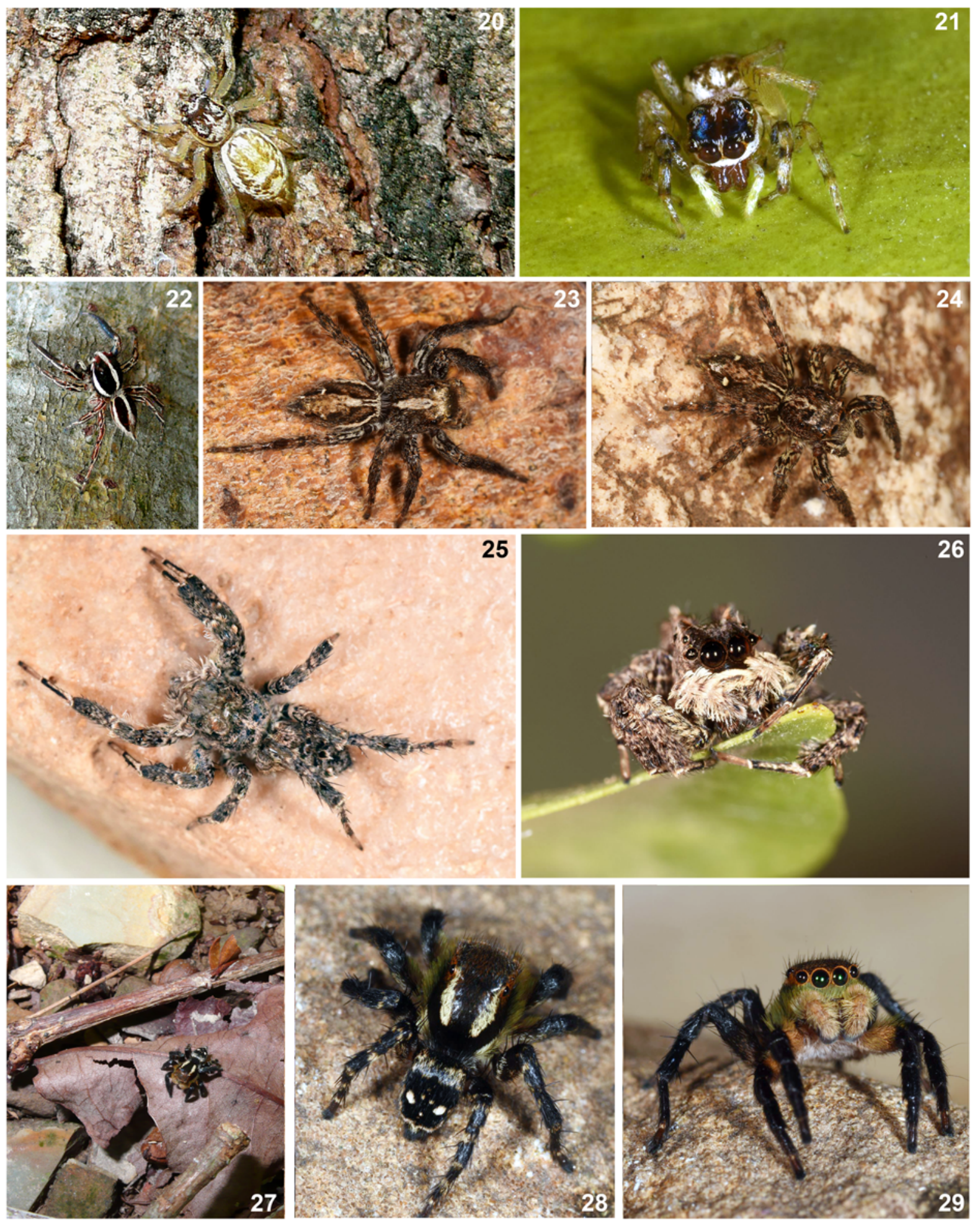

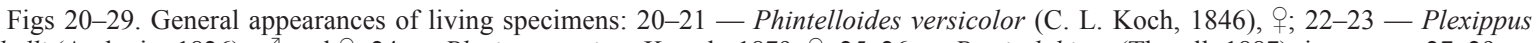
paykulli (Audouin, 1826), $O^{7}$ and + ; 24 - Plexippus setipes Karsch, 1879, , $;$; 25-26 — Portia labiata (Thorell, 1887), immature; $27-29$ Stenaelurillus abramovi Logunov, 2008, $0^{7}$.

Рис. 20-29. Внешний вид живых экземпляров: 20-21 — Phintelloides versicolor (C. L. Koch, 1846), о; 22-23 — Plexippus

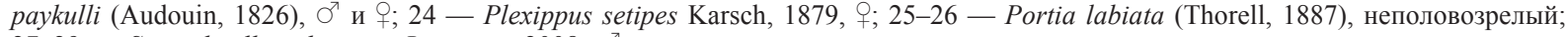
27-29 - Stenaelurillus abramovi Logunov, 2008, O’. 
Plexippus paykulli (Audouin, 1826)

Figs 22-23.

Attus paykullii Audouin, 1826: 409, pl. 7, f. 22.

Plexippus paykulli: Żabka, Gardzińska, 2017: 232, f. 1-2, 9A. MATERIAL. $1 \sigma^{7}$ (ISEA 001.8312) - [2], on tree trunk; 1 우 (ISEA 001.8311) - [3b], on tree trunk.

HABITAT. A plant dweller, also occurs on walls and other man-made constructions.

DISTRIBUTION. A widespread species of African origin tending to cosmopolitan status in the tropics, introduced to both Americas [Metzner, 2020; Nentwig et al., 2020; WSC, 2020]. In Thailand, it has been reported from many areas (see Żabka \& Gardzińska [2017]): viz., Provinces Kanchanaburi, Chiang Rai, Chiang Mai, Nong Khai, Udon Thani, Khon Kaen, Nakhon Sawan, including Bangkok lying approximately $800 \mathrm{~km}$ away from our locality. The southernmost record from Thailand.

\section{Plexippus setipes Karsch, 1879}

$$
\text { Fig. } 24 .
$$

Plexippus setipes Karsch, 1879: 89.

Plexippus setipes: Żabka, Gardzińska, 2017: 233, f. 5-6, 9C. MATERIAL. 1 (ISEA 001.8313) - [2], on tree trunk.

HABITAT. A plant dweller, found on a tree trunk.

DISTRIBUTION. Distributed from South Korea to Japan, southward to Vietnam and Thailand [Logunov, Marusik, 2000; present data]. In Thailand, the species is known from the northernmost territory: Chiang Rai Province [Żabka, Gardzińska, 2017]. Our records is the second and southernmost one in Thailand.

\section{Portia labiata (Thorell, 1887)} Figs 25-26.

MATERIAL. 1 juvenile, (ISEA) - [1], on grass.

REMARKS. The not fully formed spermathecae of the collected subadult female does not allow a reliable species identification. The habitual characters, such as the white haired clypeus, allow us to consider four Portia species which could occur in the region: $P$. albimana (Simon, 1900), P. assamensis Wanless, 1978, P. labiata (Thorell, 1887) and $P$. zhaoi Peng, Li et Chen, 2003. The following characters are evidence that the collected specimen is likely to belong to $P$. labiata: four retromarginal teeth, while other species have three teeth; palps completely fringed with long white hairs (whitish and light brown in P. assamensis and long white ventral hairs in $P$. zhaoi); tufts of dark hairs behind anterior median and outside anterior lateral eyes (light brown in $P$. albimana, whitish in $P$. assamensis and absent in P. zhaoi) (cf. Hill, 2010: f. 7-8; Murphy, Murphy, 1983: 40; Peng et al., 2003: 50-51, f. 4; Wanless, 1978: 103-107; Wanless, 1987: f. 3). Yet, the record of this species is to be considered provisional until adults have been collected from the territory of Thailand.

HABITAT. A plant dweller, also uses stone surfaces as a hunting ground. Found in the rare grass tuft.

DISTRIBUTION. From Sri Lanka to South China, Vietnam to Phillipines [WSC, 2020]. The first confirmed record for Thailand.

Stenaelurillus abramovi Logunov, 2008 Figs 27-29.

Stenaelurillus abramovi Logunov, 2008: 43, f. 1-7.
Stenaelurillus abramovi: Logunov, Azarkina, 2018: 15, f. 34 39.

MATERIAL. 1 ○ (ISEA 001.8314) - [3c], on stony detritus. HABITAT. A ground dweller, as are all other representatives of the subtribe Aelurillina. Found on soil surface (Fig. 27). A live male colouration is illustrated for the first time (Figs 27-29).

DISTRIBUTION. Thailand and Vietnam [WSC, 2020]. It is the second record from Thailand and outside the type locality. Originally described from southern Vietnam (Province Ba Ria-Vung Tau) [Logunov, 2008], later found in eastern Thailand (Trat Province) [Logunov, Azarkina, 2018]. The new locality is situated some $700 \mathrm{~km}$ south-westward of the latter. The southernmost record of the known species range.

\section{Discussion}

In total, 13 specimens belonging to 10 species and eight genera have been identified. Six of them were collected from Satun Province, five and one species were recorded from Sukhotai and Kanchanaburi Province, respectively. Six species are new to the spider fauna of Thailand (E. bulbosa, P. versicolor, P. vittata, P. labiata) or Indo-China (H. digitatus, M. nigli). Four species have the southernmost limits of their distribution either in Thailand (M. brachygnathus, P. paykulli, $P$. setipes), or of the entire range (S. abramovi).

Żabka \& Gardzińska [2017] published a checklist of the Thai Salticidae with 33 confirmed species and 13 species that needed confirmation. Unfortunately, their list contains some mistaken data. For instance, Myrmarachne paviei (Simon, 1886) was reported for Thailand, while it was actually collected from Tepong [=Thepong] situated on the territory of Cambodia, close to the modern Châmnar, Koh Kong Province. For Epeus tener Simon, 1887 it was said that "the species was originally described as Viciria cristata Thorell, 1887 (p. 393) from Chantaboun". However, Thorell [1887] described $V$. cristata from Myanmar, not from Thailand. Furthermore, Thorell compared this species with Viciria scoparia, a junior synonym of Telamonia hasselti (Thorell, 1878), which was described by Simon [1886] indeed from Chantaboun [=Chanthaburi], Siam (cf. Simon [1886: 139] and Thorell [1887: 397]). Thus, the findings of $M$. paviei and E. tener in Thailand are incorrect and are to be removed from the current species list.

Further in the same work [Żabka, Gardzińska, 2017: 231] there are two records with the same species names but different authorships: Telamonia scoparia (Simon, 1886) and T. scoparia Thorell, 1887. Based on the given distribution "from Myanmar to Sulawesi" (see Żabka \& Gardzińska [2017] and WSC [2020]), in the first case the authors apparently meant Telamonia hasselti. Under the second name, the authors seemed to mean Thiania bhamaensis Thorell, 1887, which was described from Myanmar and first recorded from Thailand by Chotwong \& Tanikawa [2013].

Metzner [2020] lists 48 species for the territory of Thailand, of which E. tener recorded by Żabka \& Gardz- 
ińska [2017] is not included. This species list includes not only published data but also identified materials from various European museum collections, for which information is in free online access (e.g., many German and Swedish museums, etc.). We have found a few species erroneously placed in the latter checklist of Thai Salticidae. Euriattus pumilio Keyserling, 1881 (sub Hasarius pumilio) was described and is known from Queensland, Australia only. Pancorius dabanis (Hogg, 1922) was described and is known from South Annam only (part of the Vietnamese territory), while it is mistakenly reported as occurring in Thailand by WSC [2020] and Metzner [2020], and also included in the list of Indian spiders [Siliwal et al., 2005]. Portia labiata is included in the Thai list following Song et al. [2002]. Yet, in the latter paper, the authors mentioned Thailand in 'Distribution', but gave no reference to the source of this information. Thus, our record is the first confirmed finding of the genus Portia in Thailand. Two species from Metzner's list [2020], as well as two species listed by Żabka \& Gardzińska [2017], should be excluded from the current checklist of Thai Salticidae until confirmation by reference to collected specimens.

Thus, with the aforementioned exceptions and newly recorded species, a verified list of Thai Salticidae currently contains 50 species from 34 genera (Table). Eleven genera are endemic to Thailand. Twenty seven

Table. A checklist and distribution of the Salticidae from Thailand. Таблица. Список видов и распространение Salticidae Таиланда.

\begin{tabular}{|c|c|}
\hline Species & $\begin{array}{l}\text { Zoogeographic Regions (sensu Kryzhanovsky } \\
\text { [2002]) }\end{array}$ \\
\hline Aelurillus thailandicus Azarkina, 2019 & Endemic of Thailand \\
\hline Asemonea tenuipes (O. Pickard-Cambridge, 1869) & Indo-Malay Region \\
\hline Bianor angulosus (Karsch, 1879) & Indo-Malay Region \\
\hline Bianor balius Thorell, 1890 & Indo-Malay Region \\
\hline Carrhotus coronatus (Simon, 1885) & Indo-Malay Region \\
\hline Chrysilla lauta Thorell, 1887 & Indo-Malay Region \\
\hline Cyrba ocellata (Kroneberg, 1875) & Palaeotropical \\
\hline Evarcha bulbosa Żabka, 1985 & Indo-Malay Region \\
\hline Eupoa lehtineni Logunov et Marusik, 2014 & Indo-Malay Region \\
\hline Eupoa pappi Logunov et Marusik, 2014 & Endemic of Thailand \\
\hline Eupoa pulchella Logunov et Marusik, 2014 & Indo-Malay Region \\
\hline Eupoa schwendingeri Logunov et Marusik, 2014 & Endemic of Thailand \\
\hline Eupoa thailandica Logunov et Marusik, 2014 & Endemic of Thailand \\
\hline Harmochirus brachiatus (Thorell, 1877) & Indo-Malay Region \\
\hline Hasarius adansoni (Audouin, 1826) & Cosmopolitan \\
\hline Holoplatys digitatus Zhou, Irfan et Peng, 2017 & Indo-Malay Region \\
\hline Hyllus diardi (Walckenaer, 1837) & Indo-Malay Region \\
\hline Hyllus pudicus Thorell, 1895 & Indo-Malay Region \\
\hline Marengo deelemanae Benjamin, 2004 & Endemic of Thailand \\
\hline Menemerus bivittatus (Dufour, 1831) & Pantropical \\
\hline Menemerus brachygnathus (Thorell, 1887) & East Palaearctic - Indo-Malay Region \\
\hline Menemerus nigli Wesołowska et Freudenschuss, 2012 & East Afrotropics - Indo-Malay Region \\
\hline Mintonia ignota Logunov et Azarkina, 2008 & Endemic of Thailand \\
\hline Myrmaplata plataleoides (O. Pickard-Cambridge, 1869) & Indo-Malay Region \\
\hline Myrmaplata turriformis (Badcock, 1917) & Indo-Malay Region \\
\hline Myrmarachne acromegalis Yamasaki et Ahmad, 2013 & Indo-Malay Region \\
\hline Myrmarachne melanocephala MacLeay, 1839 & South-East Palaearctic - Indo-Malay Region \\
\hline Nigorella petrae Prószyński, 1992 & Endemic of Thailand \\
\hline
\end{tabular}


Table (continued).

Таблица (продолжение).

\begin{tabular}{|l|l|}
\hline \multicolumn{1}{|c|}{ Species } & \multicolumn{1}{c|}{$\begin{array}{l}\text { Zoogeographic Regions (sensu Kryzhanovsky } \\
\text { [2002] }\end{array}$} \\
\hline Onomastus kaharian Benjamin, 2010 & Indo-Malay Region \\
\hline Onomastus nigrimaculatus Zhang et Li, 2005 & Indo-Malay Region \\
\hline Orcevia keyserlingi Thorell, 1890 & Indo-Malay Region \\
\hline Phintella vittata (C.L. Koch, 1846) & Indo-Malay Region \\
\hline Phintelloides versicolor (C.L. Koch, 1846) & East Palaearctic - Indo-Malay Region \\
\hline Plexippus paykulli (Audouin, 1826) & Cosmopolitan \\
\hline Plexippus petersi (Karsch, 1878) & Pantropical \\
\hline Plexippus setipes (Karsch, 1878) & Indo-Malay Region \\
\hline Portia labiata (Thorell, 1887) & Indo-Malay Region \\
\hline Rhene flavicomans Simon, 1902 & Indo-Malay Region \\
\hline Siler semiglaucus (Simon, 1901) & Indo-Malay - Papua Region \\
\hline Spartaeus spinimanus (Thorell, 1878) & Indo-Malay Region \\
\hline Spartaeus thailandicus Wanless, 1984 & Indo-Malay Region \\
\hline Stenaelurillus abramovi Logunov, 2008 & Indo-Malay Region \\
\hline Synagelides doisuthep Logunov et Hereward, 2006 & Endemic of Thailand \\
\hline Synagelides haoyai Logunov, 2017 & Endemic of Thailand \\
\hline Synagelides kochang Logunov, 2017 & Endemic of Thailand \\
\hline Telamonia hasselti (Thorell, 1878) & Indo-Malay Region \\
\hline Thiania bhamoensis (Thorell, 1887) & Indo-Malay Region \\
\hline $\begin{array}{l}\text { Thianitara thailandica } \text { Prószyński et Deeleman-Reinhold, } \\
\text { 2012 }\end{array}$ & Endemic of Thailand \\
\hline Thyene imperialis (Rossi, 1846) & South-East Palaearctic - Indo-Malay Region \\
\hline Toxeus maxillosus C.L. Koch, 1846 & Indo-Malay - Papua Region \\
\hline & \\
\hline
\end{tabular}

species are known from Indo-Malay Region (sensu Kryzhanovsky [2002]). Two species are cosmopolitan and two species are pantropical. One species is Palaeotropical. Two species are known from the south-east part of the Palaearctics to Indo-Malay Region. Two species are known from the East Palaearctics to IndoMalay Region. Two species are known from the IndoMalay to the north of Papuan Regions, one species from the East Afrotropics to Indo-Malay Region.

It is likely that with more collecting efforts many salticid species recorded from other countries of IndoChina, southern China and Indonesia will be found in Thailand, whereas the species that are currently treated as Thai endemics (Table) are likely to be found in the neighbouring countries. Yet, the current species list of Thai Salticidae should be increased at least by five times.

Acknowledgements. We are obliged to D.V. Logunov (Manchster, UK) for his critical comments and kind linguistic help that helped us to improve the ms. H. Metzner (Germany) is thanked for clarifying the distribution of and reference to Portia labiata. This work was partly supported by the Federal Fundamental Scientific Research Programme for 2013-2020 (No. AAAA-A16-116121410121-7) for GA.

\section{References}

Azarkina G.N. 2019. A new species of Aelurillus Simon, 1884 (Aranei: Salticidae) from Thailand, with the first description of the male of A. afghanus // Arthropoda Selecta. Vol.28. No.3. P.408-416. doi: 10.15298/arthsel. 28.3.05

Ali P.A., Maddison W.P., Zahid M., Butt A. 2018. New chrysilline and aelurilline jumping spiders from Pakistan (Araneae, Salticidae) // ZooKeys. Vol.783. P.1-15.

Benjamin S.P. 2004. Taxonomic revision and phylogenetic hypothesis for the jumping spider subfamily Ballinae (Araneae, Salticidae) // Zoological Journal of Linnean Society. Vol.142. P.1-82.

Benjamin S.P. 2010. Revision and cladistic analysis of the jumping spider genus Onomastus (Araneae: Salticidae) // Zoological Journal of Linnean Society. Vol.159. P.711-745. doi: 10.1111/1.1096-3642.2009.00580.x

Chatterjee S., Caleb J.T.D., Tyagi K., Kundu S., Kumar V. 2017. First report of Menemerus nigli (Araneae: Salticidae) from India // Halteres. Vol.8. P.109-111.

Chotwong W., Tanikawa A. 2013. Four spider species of the families Theridiidae, Araneidae, and Salticidae (Arachnida; Arane- 
ae) new to Thailand// Acta Arachnologica. Vol.62. No.1. P.1-

Giebel C.G. 1863. Drei und zwanzig neue und einige bekannte Spinnen der Hallischen Sammlung // Zeitschrift für die Gesammten Naturwissenschaften. Bd.21. S.306-328.

Grob P. 2015. Notes on the jumping spider Siler semiglaucus (Simon, 1901) in Thailand (Araneae: Salticidae: Heliophaninae) // Peckhamia. N.126.1. P.1-5.

Hill D.E. 2010. Sunda to Sahul: Trans-Wallacean distribution of recent salticid genera (Araneae: Salticidae) // Peckhamia. Vol.80. No.1. P.1-60.

Kim S.T., Lee S.Y. 2014. Arthropoda: Arachnida: Araneae: Clubionidae, Corinnidae, Salticidae, Segestriidae. Spiders // Invertebrate Fauna of Korea. Vol.21. No.31. P.1-186.

Kryzhanovsky O.L. 2002. [Composition and Distribution of Entomofaunas of the Globe]. Moscow: KMK Scientific Press Ltd. 273 pp. [In Russian]

Logunov D.V. 2008. A new species of the genus Stenaelurillus Simon, 1885 (Araneae: Salticidae) from Vietnam // Acta Arachnologica. Vol.57. No.1. P.43-45.

Logunov D.V. 2019. Taxonomic notes on the Harmochirina Simon, 1903 from South and South-East Asia (Aranei: Salticidae) // Arthropoda Selecta. Vol.28. No.1. P.99-112. doi 10.15298/arthsel. 28.1.08

Logunov D.V., Azarkina G.N. 2008. New species of and records for jumping spiders of the subfamily Spartaeinae (Aranei: Salticidae) // Arthropoda Selecta. Vol.16 (for 2007). No.2. P.97114.

Logunov D.V., Azarkina G.N. 2018. Redefinition and partial revision of the genus Stenaelurillus Simon, 1886 (Arachnida, Araneae, Salticidae) // European Journal of Taxonomy. Vol.430 P.1-126. doi: 10.5852/ejt.2018.430

Logunov D.V., Hereward J. 2006. New species and synonymies in the genus Synagelides Strand in Bösenberg and Strand, 1906 (Araneae: Salticidae) // Bulletin of the British arachnological Society. Vol.13. Pt.8. P.281-292.

Logunov D.V., Jäger P. 2015. Spiders from Vietnam (Arachnida: Aranei): new species and records // Russian Entomological Journal. Vol.24. No.4. P.343-363.

Logunov D.V., Marusik Yu.M. 2000. Catalogue of the jumping spiders of northern Asia (Arachnida, Araneae, Salticidae). Moscow: KMK Scientific Press Ltd. 299 pp.

Logunov D.V., Marusik Yu.M. 2014. Taxonomic notes on the genus Eupoa Żabka, 1985 (Arachnida, Araneae, Salticidae) // ZooKeys. Vol.410. P.63-93.

Metzner H. 2020. Jumping spiders (Arachnida: Araneae: Salticidae) of the world. Online at https://www.jumping-spiders.com, accessed on January 2020.

Murphy J., Murphy F. 1983. More about Portia (Araneae: Salticidae) // Bulletin of the British arachnological Society. Vol.6. Pt.1. P.37-45.

Nentwig W., Blick T., Bosmans R., Gloor D., Hänggi A., Kropf C. 2020. Spiders of Europe. Online at https://www.araneae.nmbe. ch, version of 01.2020 , accessed on 30 January 2020.

Peng X.J. 1989. New records of Salticidae from China (Arachnida, Araneae) // Journal of Natural Science of Hunan Normal University. Vol.12. P.158-165.

Peng X.J., Li S.Q., Chen J. 2003. Description of Portia zhaoi sp. nov. from Guangxi, China (Araneae, Salticidae) // Acta Zootaxonomica Sinica. Vol.28. P.50-52.
Prószyński J. 1992a. Salticidae (Araneae) of the Old World and Pacific Islands in several US collections // Annalales Zoologici. T.44. No. 8. P.87-163.

Prószyński J. 1992b. Salticidae (Araneae) of India in the collection of the Hungarian National Natural History Museum in Budapest // Annales Zoologici. T.44. No.9. P.165-277.

Prószyński J. 2017. Remarks on the genus Plexippus C. L. Koch, 1846 (Araneae: Salticidae) // Ecologica Montenegrina.T.13. S.39-69.

Prószyński J., Deeleman-Reinhold C.L. 2012. Description of some Salticidae (Aranei) from the Malay archipelago. II. Salticidae of Java and Sumatra, with comments on related species // Arthropoda Selecta. Vol.21. No.1. P.29-60.

Roewer C.F. 1955. Katalog der Araneae von 1758 bis 1940. Bruxelles. Bd.2a. S.1-1751.

Roy T.K., Saha S., Raychaudhuri D. 2016. A treatise on the jumping spiders (Araneae: Salticidae) of tea ecosystem of Dooars, West Bengal, India // World Scientific News. Vol.53. No.1. P.1-66.

Siliwal, M., Molur S., Biswas B.K. 2005. Indian spiders (Arachnida, Araneae): updated checklist 2005 // Zoo's Print Journal. V.20. No.10. P.1999-2049.

Simon E. 1886. Arachnides recueillis par M. A. Pavie (sous chef du service des postes au Cambodge) dans le royaume de Siam, au Cambodge et en Cochinchine // Actes de la Société Linnéenne de Bordeaux. T.40. P.137-166.

Shorthouse D.P. SimpleMappr, an online tool to produce publication-quality point maps. Available from http:// www.simplemappr.net [accessed 30 January 2020].

Song D.X., Zhang J.X., Li D. 2002. A checklist of spiders from Singapore (Arachnida: Araneae) // Raffles Bulletin of Zoology. T.50. No.2. P.359-388.

Wanless F.R. 1978. A revision of the spider genus Portia (Araneae: Salticidae) // Bulletin of the British Museum of Natural History (Zool.). Vol.34. No.3. P.83-124.

Wanless F.R. 1980. A revision of the spider genera Asemonea and Pandisus (Araneae: Salticidae) // Bulletin of the British Museum of Natural History (Zool.). Vol.39. No.4. P.213-257.

Wanless F.R. 1984. A revision of the spider genus Cyrba (Araneae: Salticidae) with the description of a new presumptive pheromone dispersing organ // Bulletin of the British Museum of Natural History (Zool.). Vol.47. No.7. P.445-481.

Wesołowska W., Freudenschuss M. 2012. A new species of Menemerus from Pakistan (Araneae: Salticidae) // Genus. Vol.23. No.3. P.449-453.

World Spider Catalog. 2020. Natural History Museum Bern, online at https://wsc.nmbe.ch, version 21.0 , accessed on 30 January 2020.

Yin C.M., Peng X.J., Yan H.M., Bao Y.H., Xu X., Tang G., Zhou Q.S., Liu P. 2012. Fauna Hunan: Araneae in Hunan, China. Changsha: Hunan Science and Technology Press. 1590 pp.

Żabka M. 1985. Systematic and zoogeographic study on the family Salticidae (Araneae) from Viet-Nam // Annalales Zoologici. T.39. No.11. S.197-485.

Żabka M., Gardzińska J. 2017. Salticidae of Thailand. part 1, genera Plexippus C.L. Koch, 1846 and Burmattus Prószyñski, 1992 // Annales Zoologici. T.67. No.2. S.229-242.

Zhou G.C., Irfan M., Peng X.J. 2017. A new spider species of the genus Holoplatys Simon, 1885 from the Southern China (Araneae: Salticidae) // Acta Arachnologica Sinica. Vol.26. No.1. P.1-5. 